DOI: http://dx.doi.org/10.33846/ghs5316

\title{
Gambaran Pengetahuan dan Sikap Perawat Ruang OK dalam Pemberian Inisiasi Menyusu Dini (IMD) di RSUD Dr. Hadrianus Sinaga Pangururan Kabupaten Samosir Tahun 2019
}

\author{
Ricard Fredrik Marpaung (koresponden) \\ (Program Studi Ilmu Keperawatan, Universitas Efarina) \\ Rostio Derlina \\ (Program Studi IImu Keperawatan, Universitas Efarina)
}

\begin{abstract}
ABSTRAK
Tujuan penelitian ini adalah mengetahui gambaran pengetahuan dan sikap perawat ruang OK dalam pemberian inisias menyusui dini (IMD) di RSUD Dr. Hadrianus Sinaga Pangururan Kabupaten Samosir Tahun 2017. Jenis penelitian ini adalah cross-sectional. Populasi dalam penelitian ini adalah seluruh perawat ruang OK RSUD Dr. Hadrianus Sinaga Pangururan Kabupaten Samosir yaitu sebanyak 10 orang. Data dikumpulkan melalui pengisian kuesioner dan dianalisis secara deskriptif berupa frekuensi dan persentase. Didapatkan bahwa: 1) mayoritas mempunyai pengetahuan cukup yaitu sebanyak 4 orang (40\%) sedangkan minoritas mempunyai pengetahuan baik yaitu sebanyak 3 orang $(30 \%)$ dan pengetahuan kurang yaitu sebanyak 3 orang $(30 \%)$, 2) mayoritas mempunyai sikap setuju yaitu sebanyak 7 orang $(70 \%)$ sedangkan minoritas sikap tidak setuju yaitu sebanyak 3 orang $(30 \%)$.
\end{abstract}

Kata kunci: inisiasi menyusu dini (IMD); pengetahuan; sikap

\section{PENDAHULUAN}

Inisiasi menyusu Dini (IMD) adalah suatu proses membiarkan bayi dengan nalurinya sendiri untuk menyusui sesegera dalam satu jam pertama setelah lahir,bersamaan dengan kontak antara kulit bayi dengan kulit ibu (Depkes RI, 2008). Kebijakan inisiasi menyusu dini telah disosialisasikan di Indonesia sejak Agustus 2007 (Roesli, 2009). World Health Organization (WHO) telah merekomendasikan kepada semua bayi untuk mendapatkan kolostrum yaitu ASI pada hari pertama dan kedua untuk melawan berbagai infeksi dan mendapatkan ASI eksklusif selama 6 bulan (Kemenkes, 2012).

Kebijakan pelaksanaan inisiasi menyusu dinitersebut juga diharapkan dapat menurunkan kematian bayi (AKB) sesuai dengan pencapaian Millineum Development Goals (MDGs) sebanyak 23 per 1000 kelahiran hidup di tahun 2015 (Depkes, 2013).

Indonesia adalah salah satu Negara di Asia yang mengalami kemajuan pesat dalam hal pengurangan kematian balita. Namun hingga kini, angka kematian bayi baru lahir dan bayi masih tetap memperlambat keseluruhan kemajuan Indonesia dalam mengurangi angka kematian balita, sehingga diperlukan akselerasi perawatan bagi bayi baru lahir. Tahun 2008, angka kematian bayi atau infant mortality rate (IMR)di Indonesia masih cukup tinggi yaitu 31,04/1000 kelahiran hidup artinya terdapat 3104 bayi meninggal setiap 1000 kelahiran. Salah satu metode yang efektif adalah kontak kulit ke kulit dan inisiasi menyusu dini bagi bayi baru lahir dalam masa satu jam pertama sejak bayi dilahirkan. Sebuah studi yang dipublikasikan di pediatrics tahun 2006 menunjukkan bahwa praktik ini dapat mengurangi kematian bayi baru lahir dari infeksi, diare, hipotermia dan masalah pernapasan. (Sardjunani.N, 2010)

Inisiasi menyusu Dini akan sangat membantu dalam keberlangsungan pemberian ASI eksklusif (ASI saja) dan lama menyusuii. Dengan demikian, bayi akan terpenuhi kebutuhannya hingga usia 2 tahun dan mencegah anak kurang gizi. Bayi yang baru lahir sangat rentan terhadap kematian akibat hipotermia. Namun 16 persen kematian bayi dapat dicegah melalui pemberian ASI pada sejak hari pertama dilahirkan. Angka ini naik menjadi 22 persen jika pemberian ASI dimulai satu jam setelah kelahiran atau dikenal dengan istilah inisiasi menyusu dini (IMD). (Asep Candra, 2010).

Angka menyusuii dini di Indonesia masih rendah, survey terakhir (SDKI, 2007) menemukan bahwa bayi yang diberi ASI ekskusif hanya terjadi pada 32 persendari total keseluruhan bayi yang dilahirkan, hal ini lebih rendah dibandingkan hasil survey serupa (SDKI 2002/03), yaitu 40 persen. Dengan demikian, promosi pemberian ASI ekslusif bisa menjadi kebijakan yang penting dalam menurunkan angka kematian bayi baru lahir, dan informasi tentang ini harus ditujukan kepada para pembuat kebijakan, penyedia layanan dan masyarakat luas. (Sardjunani.N, 2010)

Bayi yang baru lahir sangat rentan terhadap kematian akibat hipotermia. Namun 16 persen kematian bayi dapat dicegah melalui pemberian ASI pada sejak hari pertama dilahirkan. Angka ini 
naik menjadi 22 persen jika pemberian ASI dimulai satu jam setelah kelahiran atau dikenal dengan istilah inisiasi menyusu dini (IMD) (Asep Candra, 2010).

Bidan dan perawat merupakan tenaga kesehatan yang paling berperan dalam melaksanakan IMD karena ibu tidak dapat melakukan IMD tanpa bantuan dan fasilitasi dari perawat dan bidan. Misalnya untuk mendukung ASI eksklusif 6 bulan, penelitian yg dilakukan terhadap kelompok ibu yang memberikan ASI eksklusif dan ASI tidak eksklusif menunjukkan bahwa sebagian besar informan ASI eksklusif difasilitasi IMD oleh bidan atau perawat sedangkan sebagian besar informan ASI tidak eksklusif tidak difasilitasi IMD. Dalam penelitian tersebut dari 7 informan yang tidak IMD, hanya 3 informan yang alasannya karena hal yang sulit dihindari, yaitu ibu sakit sehabis operasi caesar, bayi harus langsung masuk inkubator, dan ibu mengalami perdarahan. Sedangkan 4 informan lainnya tidak IMD karena alasan yang sebenarnya bisa dihindari yaitu bayi akan dibersihkan dan dibedong terlebih dahulu (Fika \& Syafiq, 2009).

Angka kematian bayi (AKB) atau Infant Mortality Rate (IMR) dipengaruhi oleh beberapa faktor. Diantaranya adalah masalah yang terkait dengan gizi ibu pada waktu melahirkan dan gizi bayi itu sendiri. Kedua hal ini bisa menjadi factor langsung maupun tidak langsung penyebab kematian bayi. Oleh karena itu, pemenuhan kebutuhan gizi bayi sangat perlu mendapat perhatian yang serius. Hal ini tentu dapat dilakukan dengan mudah oleh para ibu karena pada dasarnya pemenuhan gizi untuk bayi yang paling sempurna dan paling murah adalah dari ASI.Keberhasilan inisiasi menyusu dini sangat dipengaruhi oleh sikap, pengetahuan, dan motivasi baik ibu hamil, tenaga kesehatan atau penolong persalinan itu sendiri (Lin-lin Su, 2007).

Berdasarkan hasil survey awal di RSU Dr. Hadrianus Sinaga Pangururan bahwa pelaksanaan Insiasi Menyusuii Dini pada saat ini belum terlaksana dengan baik. Dari data ditemukan Pelaksanaan Insiasi Menyusuii Dini lebih dominan dilakukan pada ibu yang melahirkan dengan cara normal dibandingkan dengan ibu yang melahirkan dengan proses caesar. Hal ini dikarenakan faktor-faktor tertentu yang membuat perawat tidak melakukan Insiasi Menyusuii Dini pada bayi dan ibu, terutama faktor tingkat pengetahuan perawat dalam melakukan Insiasi Menyusuii Dini atau memberikan pendidikan kesehatan kepada ibu yang melahirkan melalui Caesar.

Tujuan penelelitian ini adalah mengetahui gambaran pengetahuan dan sikap perawat ruang OK dalam pemberian inisiasi menyusu dini (IMD) Di RSUD Dr. Hadrianus Sinaga PangururanKabupaten Samosir Tahun 2017.

\section{METODE}

Jenis penelitian ini adalah cross sectional yaitu merupakan rancangan penelitian dengan melakukan pengamatan pada saat bersamaan (Hidayat, 2009). Penelitian dilaksanakan di RSUD Dr. Hadrianus Sinaga Pangururan Kabupaten Samosir. Penelitian ini akan dilaksanakan pada MeiAgustus 2017. Populasi dalam penelitian ini adalah seluruh perawat ruang OK RSUD Dr. Hadrianus Sinaga Pangururan Kabupaten Samosir yaitu sebanyak 10 orang. Data dikumpulkan melalui pengisian kuesioner dan dianalisis secara deskriptif berupa frekuensi dan persentase (Nugroho, 2014).

HASIL

Tabel 1. Distribusi umur responden

\begin{tabular}{|c|c|c|c|}
\hline No & Umur & $f$ & $\%$ \\
\hline 1 & 20-30 Tahun & 2 & 20 \\
\hline 2 & $31-40$ Tahun & 6 & 60 \\
\hline 3 & $>40$ Tahun & 2 & 20 \\
\hline & Jumlah & 10 & 100 \\
\hline
\end{tabular}

Berdasarkan Tabel 1 diperoleh data responden mayoritas mempunyai umur 31-40 tahun yaitu sebanyak 6 orang (60\%) sedangkan minoritas mempunyai umur 20-30 tahun yaitu sebanyak 2 orang $(20 \%)$ danumur $>40$ tahunyaitusebanyak 2 orang $(20 \%)$ 
Tabel 2. Distribusi jenis kelamin responden

\begin{tabular}{|c|c|c|c|}
\hline No & Jenis kelamin & $f$ & $\%$ \\
\hline 1 & Laki-laki & 3 & 30 \\
\hline 2 & Perempuan & 7 & 70 \\
\hline & Jumlah & 10 & 100 \\
\hline
\end{tabular}

Berdasarkan Tabel 2 diperoleh data responden mayoritas mempunyai jenis kelamin perempuan yaitu 7 orang $(70 \%)$ sedangkan minoritas mempunyai jenis kelamin laki-laki yaitu 3 orang $(30 \%)$.

Tabel 3. Distribusi pendidikan responden

\begin{tabular}{|c|c|c|c|}
\hline No & Pendidikan & $\mathrm{f}$ & $\%$ \\
\hline 1 & Diploma III & 9 & 90 \\
\hline 2 & S1 Keperawatan & 1 & 10 \\
\hline & Jumlah & 10 & 100 \\
\hline
\end{tabular}

Berdasarkan 3 diperoleh data responden mayoritas responden mempunyai pendidikan Diploma III yaitu sebanyak 9 orang (90\%) sedangkan minoritas mempunyai pendidikan S1 Keperawatan yaitu sebanyak 1 orang $(10 \%)$.

Tabel 4. Distribusi lama bekerja responden

\begin{tabular}{|c|c|c|c|}
\hline No & Lama Bekerja & $f$ & $\%$ \\
\hline 1 & 5-10 Tahun & 3 & 30 \\
\hline 2 & $>10$ Tahun & 7 & 70 \\
\hline & Jumlah & 10 & 100 \\
\hline
\end{tabular}

Berdasarkan Tabel 4 diperoleh data responden mayoritas sudah lama bekerja $>10$ tahun yaitu sebanyak 7 orang $(70 \%)$, minoritas sudah bekerja selama 5-10 tahun yaitu sebanyak 3 orang (30\%).

Tabel 5. Distribusi pengetahuan responden

\begin{tabular}{|c|c|c|c|}
\hline No & Pengetahuan & $\mathrm{F}$ & $\%$ \\
\hline 1 & Baik & 7 & 70 \\
\hline 2 & Kurang & 3 & 30 \\
\hline & Jumlah & 10 & 100 \\
\hline
\end{tabular}

Berdasarkan Tabel 5 diperoleh data responden mayoritas mempunyai pengetahuan Baik yaitu sebanyak 7 orang $(70 \%)$ sedangkan minoritas mempunyai pengetahuan kurang yaitu sebanyak 3 orang (30\%).

Tabel 6. Distribusi sikap responden

\begin{tabular}{|c|c|c|c|}
\hline No & Sikap & f & $\%$ \\
\hline 1 & Setuju & 7 & 70 \\
\hline 2 & Tidak Setuju & 3 & 30 \\
\hline & & 10 & 100 \\
\hline
\end{tabular}

Berdasarkan Tabel 6 diperoleh data responden mayoritas mempunyai sikap setuju yaitu sebanyak 7 orang (70\%) sedangkan minoritas sikap tidak setuju yaitu sebanyak 3 orang $(30 \%)$.

\section{PEMBAHASAN}

Hasil penelitian menunjukkan bahwa Gambaran Pengetahuan dan sikap Perawat di ruang OK dalam pemberian inisiasi menyusu dini di RSUD dr. Hadrianus Sinaga Pangururan terhadap Pelaksanaan Inisiasi menyusu Dini Berdasarkan hasil uji Cross Sectiona. 
Pengetahuan perawat dipengaruhi oleh faktor internal dan faktor eksternal. Faktor internal di antaranya yaitu tingkat kecerdasan dan tingkat emosi. Karena tingkat pendidikan seorang perawat sangat mempengaruhi pengetahuan, semakin tinggi pendidikan seorang perawat maka pengetahuan semakin baik. Faktor eksternal yaitu lingkungan sosial budaya seorang perawat. Di lingkungan yang berendidikan DIII tingkat pengetahuannya lebih baik dari mayoritas penduduknya yang berpendidikan SD.

Hasil penelitian ini sesuai dengan pendapat Notoatmodjo (2010) yang menyatakan bahwa pengetahuan atau kognitif merupakan dominan. Sangat penting dalam membentuk perilaku atau tindakan seseorang. Tingkat pengetahuan seseorang memiliki hubungan yang positif terhadap tingkah laku yang dilakukannya, berarti semakin kurang pengetahuan seseorang, maka semakin jarang melaksanakan inisiasi menyusu dini. Hal ini didukung oleh teori Lawrance Green dalam Notoatmodjo (2009) yang mengatakan bahwa perilaku seseorang dipengaruhi oleh faktor pengetahuan.

Pengaruh Sikap Perawat terhadap Pelaksanaan IMD berdasarkan hasil uji statistic koefisien korelasi spearman rank dengan menggunakan SPSS versi 21 didapat hasil nilai koefisien korelasi (Per hitung) sebesar 0,396 dan $p=0,020 \quad(p<0,05)$. maka dikatakan bahwa hipotesis diterima dengan baik atau ada gambaran pengetahuan dan sikap perawat terhadap pelaksanaan inisiasi menyusui dini di ruang OK RSUD Dr. Hadrianus Sinaga Pangururan Kabupaten Samosir Tahun 2017maudansetujudalammelakukaninisiasimenyusuidini.

Dalam hal ini sikap merupakan kesiapan atau kesediaan untuk bertindak dan bukan merupakan pelaksanaan motif tertentu. Sikap belum merupakan tindakan atau aktivitas, tetapi merupakan predisposisi memperoleh pengetahuan. Hal ini perawat dapat dipengaruhi oleh pengalaman pribadi atau pengalaman orang lain yang dianggap itu dihadapi pada masa lalu (Notoatmodjo, 2009). tersebut dapat terkumpul menjadi satu dalam diri seorang perawat sehingga akan membentuk suatu peran yang tujuannya untuk menentukan tindakan. Tindakan tersebut dapat berupa baik atau positif maupun buruk atau negatif. Sikap menunjukan bagaimana perilaku atau kecenderungan berperilaku yang ada dalam diri seseorang yang berkaitan dengan objek sikap yang dihadapinya (Azwar, 2009).

Kaitan ini didasarkan oleh asumsi bahwa kepercayaan dan perasaan banyak mempengaruhi perilaku. Kecenderungan berperilaku secara konsisten selaras dengan kepercayaan dan perasaan ini membentuk individual. Pengalaman merupakan guru yang terbaikdalammemperhatikan stimulus. Pepatah tersebut dapat diartikan diberikan (objek) bahwa semakin sering kita lakukan sosialisasi IMD maka semakin meningkat pengetahuan.

Seseorang memperoleh pengetahuan dapat dipengaruhi dengan cara mengulang oleh pengalaman pribadi atau pengalaman orang lain yang dianggap dapat memecahkan permasalahan yang penting dan dipengaruhi kebudayaan (Notoatmodjo,2009). Hal tersebut dapat terkumpul menjadi satu Hasil penelitian menunjukkan dalam diri seorang perawat bahwa semakin lama seseorang bekerja akan membentuk banyak pengalaman sehingga semakin baik hasil pekerjaan dalam tindakan. Tindakan tersebut dapat menjadi tanggung jawabnya, demikian berupa baik atau positif maupun buruk atau negatif. pelaksanaan pekerjaan, dalam hal ini Sikap menunjukan bagaimana sebagai perawat untuk perilaku atau kecenderungan membantu ibu persalinan dalam berperilaku yang ada dalam diri melaksanakan IMD pada bayinya. seseorang yang berkaitan dengan objek sikap yang dihadapinya (Azwar, 2009).

Menurut yang saya teliti di RSUD Dr.Hardianus Sinaga Pangururan gambaran pengetahuan dan sikap perawat Ruang OK dalam pemberian inisiasi menyusu dini,sudah lebih baik dan mempunyai pengetahuan lebih baik karena pendidikan diatas D3 Keperawatan. Dalam table 5.1.1 ada data responden mayoritas perempuan karena lebih bisa mengerti dan memahami perasaan seorang ibu.Sedangkan laki laki ada dalam ruang OK di karenakan di ruang OK di butuhkan juga tenaga untuk melengkapi alat juga untuk mengangkat pasien dari tempat tidur.

\section{KESIMPULAN}

Setelah dilakukan penelitian mengenai Gambaran Pengetahuan Dan Sikap Perawat Ruang OK Dalam Pemberian Inisiasi Menyusu Dini (IMD) Di RSUD Dr. Hadrianus Sinaga Pangururan Kabupaten Samosir Tahun 2017 dengan 10 responden maka dapat diperoleh hasil sebagai berikut :

1. Mayoritas mempunyai pengetahuan cukup yaitu sebanyak 4 orang $(40 \%)$ sedangkan minoritas mempunyai pengetahuan baik yaitu sebanyak 3 orang (30\%) dan pengetahuan kurang yaitu sebanyak 3 orang $(30 \%)$. 
2. Mayoritas mempunyai sikap setuju yaitu sebanyak 7 orang $(70 \%)$ sedangkan minoritas sikap tidak setuju yaitu sebanyak 3 orang $(30 \%)$

\section{DAFTAR PUSTAKA}

1. A. Riyanto. 2009. Aplikasi Metodologi Penelitian Kesehatan.Yogyakarta: Nuha Medika

2. Aziz A. Hidayat. 2009. Metode Penelitian Kebidanan dan Teknik Analisis Data. Jakarta: Salemba Medika.

3. Azwar, S., 2007, Sikap Manusia; Teori dan Pengukurannya, Pustaka Belajar, Yogyakarta

4. Caiwardana, 2012, Pengertian Pengetahuan dan sikap Menurut Para Ahli

5. Dahlan, Muhamad Sopiyudin. 2012. Statistik Untuk Kedokteran dan Kesehatan. Jakarta: Salemba Medik

6. DepKes. RI, 2010, Kesehatan Reproduksi, Jakarta

7. Februhartanty, Judhiastuty, 2009, ASI dari Ayah Untuk Ibu dan Bayi, Jakarta: Semesta Media

8. Kartika Sari, E, 2008, Pemberian Inisiasi Menyusu Dini Pada bayi baru lahir di RSUD Banjarbaru. Karya Tulis IImiah

9. Notoatmodjo, S., 2007, Kesehatan Masyarakat: IImu dan Seni, Rineka Cipta, Jakarta

10. Notoatmodjo, S., 2010, Promosi Kesehatan: Teori dan Aplikasi. Rineka Cipta, Jakarta

11. Notoatmodjo, S., 2010, Metodologi Penelitian Kesehatan, Rineka Cipta, Jakarta

12. Nugroho HSW. Analisis Data Secara Deskriptif untuk Data Kategorik. Ponorogo: FORIKES; 2014.

13. Nursalam. 2009. Konsep Dan Penerapan Metodologi Penelitian IImu Keperawatan: Pedoman Skripsi, Tesis, Dan Instrumen Penelitian. Jakarta: Salemba Medika. Patricia A, Potter. Anne G. Perry. 2005. Buku Ajar Fundamental Keperawatan

14. Prasetyono Dwi, Sunar, 2009, Buku Pintar ASI Esklusif (Cetakan I). Yogyakarta: Diva Press.

15. Purwanti Hubertin, Sri, 2004, Konsep Penerapan ASI Esklusif (Cetakan I). Jakarta; EGC.

16. Roesli, U, 2008, Inisiasi Menyusu Dini plus ASI Ekslusif, Penerbit Pustaka Bunda, Jakarta.

17. Roesli, U, 2008, Inisiasi Menyusu Dini, 2008. Diakses pada tanggal 05 Agustus 2017

18. Suryoprajogo, Nadine, 2009, Keajaiban Menyusui (Cetakan I). Jogjakarta Survey Demografi dan Kesehatan Indonesia, Jakarta, 2008

19. Wawan dan Dewi, 2010, Teori dan Pengukuran Pengetahuan, Sikap dan Perilaku Manusia, Nuha Medika, Yogyakarta

20. Yunanto, A, 2007, Inisiasi Menyusu Dini Menuju Tumbuh Kebang Optimal. Bahan Kuliah IImu Kesehatan Anak. SMF Anak RSUD Ulin/FK. Universitas Lambung Mangkurat, Banjarmasin 